Mini Review

\title{
The diagnostic and therapeutic approach to a child having simultaneous renal and testicular mass
}

\begin{abstract}
Twelve \% of Wilms' tumor patients have metastases at initial presentation. The hematogenous metastasis is most common in lung, followed by liver, contralateral kidney, bone and brain. In the literature (1928-2016) 12 cases of testicular/ paratesticular metastasis of Wilms' tumor has been reported. Here, we report a child having Wilms' tumor with testicular metastasis, with discussion on how to approach the children having simultaneous renal and testicular mass.
\end{abstract}

Keywords: metastastic wilms' tumor; patent processes vaginalis; pediatric renal lump; Testicular metastasis; wilms' tumor
Volume 6 Issue I - 2017

\author{
Sunita Singh,' Jiledar Rawat, ${ }^{2}$ Niraj kumar \\ srivastava,' Intezar Ahmed ${ }^{3}$ \\ 'Department of Surgery, All India Institute of Medical sciences \\ Raipur, India \\ ${ }^{2}$ Department of Pediatric Surgery, King George?s Medical \\ University, India \\ ${ }^{3}$ Department of Pediatric Surgery, All India Institute of Medical \\ sciences, India
}

\begin{abstract}
Correspondence: Sunita Singh (MS, MCh, paediatric surgery) Assistant Prof. Dept of Surgery, All India Institute of Medical Sciences, Raipur, Chhattisgarh, India, Tel 8518887725,
\end{abstract} Email drsunitasingh@gmail.com

Received: October 3I, 2016 | Published: January 03, 2017
Abbreviations: AFP, alfa feto protein, CECT, contrast enhanced computer tomography, chemo: Chemotherapy; hCG, human chorionic gonadotropin hormone, $\mathrm{HIO}$, high inguinal orchiectomy, i.e, that is; $\mathrm{LDH}$ 1, lactate dehydrogenase isoenzyme 1; RT, radiotherapy; SIOP, societe internationale d'oncologie pediatrique, WT, wilms' tumor

\section{Introduction}

Wilms' tumor (WT)/ Nephroblastoma is the second common abdominal malignancy and most common malignant renal tumor in children. ${ }^{1}$ Twelve $\%$ of WT patients have metastases at initial presentation. ${ }^{2}$ Common hematogenous metastatic site of WT include the lung, liver, and contralateral kidney. Less common sites include the bone, skin, brain, and orbit. ${ }^{2}$ The lung is most common hematogenous metastatic site. The lymphatic spreads to lymph nodes are the most common. The rare site of metastasis are mediastinum and testis. ${ }^{1-12}$

In adults most frequent primary tumors metastatic to spermatic cord and epididymis are carcinomas from the stomach, prostate, colon, pancreas, appendix, and renal (renal cell carcinoma. ${ }^{13,14}$

It is utmost important to evaluate the genitalia in pediatric patients presenting with renal lump, as there may be syndromic association, (cryptorchidism, pseudohermaphroditism), vericocele (tumor compressing testicular veins) hydrocele (subclinical metastasis having reactive hydrocele ), patent processes vaginalis etc. ${ }^{15,16}$ To the best of our search (all languages, both indexed non indexed journal) with the key words testicular metastasis, paratesticular metastasis, metastatic Wilms' tumor in the literature from 1928 to 2016, we found 12 cases of testicular/ paratesticular metastasis of WT. ${ }^{1-12}$ We excluded the cases of extrarenal scrotal WT (scrotal WT without primary renal involvement) arising from heterotropc anlage. ${ }^{17}$ Author here reported a rare case of WT with synchronous epsilateral testicular metastasis, with discussion of diagnostic and therapeutic approach for children presenting with renal lump and testicular mass.

\section{Case presentation}

A 3.5-year-old male was referred to us with left renal lump, gross haematuria, and a left testicular mass for 2 months. There was no history of fever, weight loss, cough, and hemoptesis etc. On examination a $12 \times 8 \mathrm{~cm}$, non-tender, hard, smooth, bimannualy palpable lump crossing the midline was present in left flank. Another $6.0 \times 4.0 \mathrm{~cm}$, well defined, smooth, non tender, hard, transilluminant negative left testicular mass was also present.

Blood biochemistory was normal except anemia. The serum Alfa Feto Protein (AFP), Humon Chorionic Gonadotropin (HCG) and Serum isoenzyme lactate dehydrogenase (LDH 1) were within normal limits. Ultrasonography suggested normal contralateral kidney and testicle. Contrast enhanced computer tomography (CECT) scan of abdomen with scrotum (shielding of right testicle) showed $16 \times 10 \mathrm{~cm}$ left renal mass compressing adjacent structures, retroperitoneal lymph node enlargement, invasion of left renal vessels and inferior vena cava (below diaphragm) with a heterogenous $6 \times 4.5 \mathrm{~cm}$ left testicular mass (Figure 1). Further radiology didn't reveled any other site of metastasis.

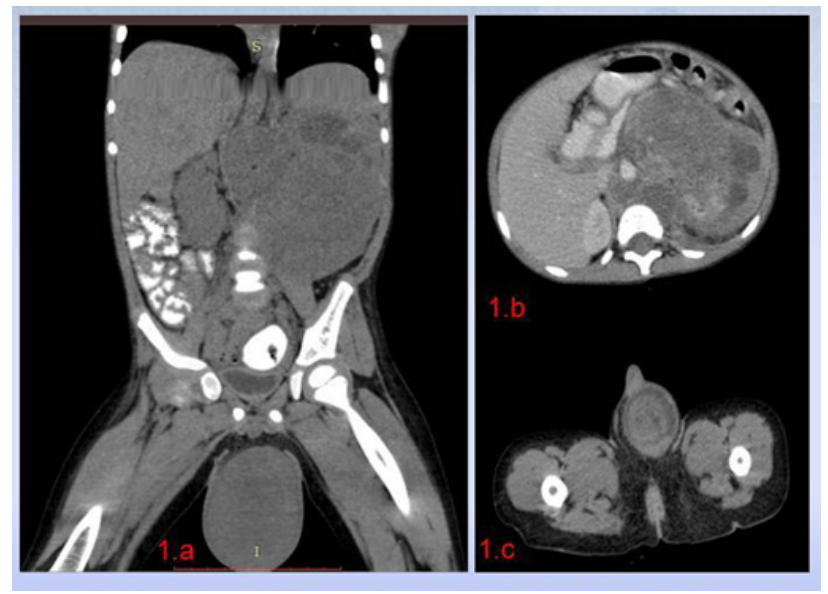

Figure I I.a, b: 64 slice contrast enhanced CT scan of abdomen in coronal and axial section showing $16 \times 10 \mathrm{~cm}$ sized heterogenous, left Renal mass, compressing adjacent structures, displacing inferior vena cava with multiple retroperitoneal lymph node enlargement and homogenous $6 \times 4.5 \mathrm{~cm}$ sized left testicular mass; .I.c axial section of testicular mass showing homogenous testicular mass. 
We adopted Societe Internationale D'oncologie Pediatrique (SIOP) protocol and through left transverse incision biopsy of left renal mass with hilar \& para-aortic lymph node sampling was done. ${ }^{18}$ The procedure was accompanied by early control of left testicular vessels and radical orchiectomy through same incision. Histopathology showed blastemal type WT having diffuse anaplasia. The histology of left testis was same, with spermatic vessels involvement, and spared epididymis and spermatic cord. Hence we came to the diagnosis of testicular metastasis of primary WT.

We planned to administer the neoadjuvant chemotherapy according to SIOP stage III with high risk histology [19]. Vincristine, Adriamycin, Doxorubicin, Cyclophosphamide was administered with abdominal radiation therapy (RT). Five weeks after chemo-radio therapy gross haematurea settled down, but imaging didn't showed regression in the size of renal or testicular mass. The chemotherapy shifted to etoposide, carboplatin and cyclophosphamide for 5 week with RT. The child was planned for surgery, but he lost the follow up.

\section{Discussion}

The incidence of WT is 7.6 cases for every million children less than 15 years of age or 1 case per 10,000 infants. ${ }^{3} \mathrm{WT}$ is associated with congenital syndromes in $10 \%$ of cases, including sporadic aniridia, isolated hemihypertrophy, Denys-Drash syndrome (nephropathy, renal failure, male pseudohermaphroditism, and Wilms' tumor), genital anomalies, Beckwith-Wiedemann syndrome [visceromegaly, macroglossia, omphalocele, and hyperinsulinemic hypoglycemia in infancy and WAGR complex (WT with aniridia, genitourinary malformations, and mental retardation). ${ }^{15,16}$ This suggested a genetic predisposition to this tumor but literature analysis didn't (Table 1) suggested any genetic/ familial predisposition for testicular metastasis.

Table I Literature review of previously reported cases of synchronous/asynchronous testicular metastasis of renal tumor

\begin{tabular}{|c|c|c|c|c|c|c|c|c|}
\hline S.No. & Author's & $\begin{array}{l}\text { Age } \\
(\mathrm{M})\end{array}$ & $\begin{array}{l}\text { Wilms' } \\
\text { tumor Side }\end{array}$ & $\begin{array}{l}\text { Testicular } \\
\text { metastasis Side }\end{array}$ & $\begin{array}{l}\text { Presentation of } \\
\text { testicular mass }\end{array}$ & $\begin{array}{l}\text { Treatment of testicular } \\
\text { metastasis }\end{array}$ & $\begin{array}{l}\text { Histopathology } \\
\text { of testicular } \\
\text { SPECIMEN }\end{array}$ & Outcome \\
\hline I & Dew et al.' & 27 & $\mathrm{Lt}$ & $\mathrm{Lt}$ & $\begin{array}{l}\text { Testicular mass } 6 \text { m Post } \\
\text { Radical Nephrectomy }\end{array}$ & - $\mathrm{HIO}$ & $\begin{array}{l}\text { Testis, Epidydymis, } \\
\text { spermatic cord, } \\
\text { spermatic vein }\end{array}$ & $\begin{array}{l}\text { Died with } \\
\text { pulmonary } \\
\text { metastasis } \\
\text { within } 4 \mathrm{~m} \\
\text { of diagnosis } \\
\text { testicular } \\
\text { metastasis }\end{array}$ \\
\hline 2 & Yadav $\mathrm{K}$ et al. ${ }^{2}$ & $9 \mathrm{~m}$ & $\mathrm{Lt}$ & $\mathrm{Lt}$ & $\begin{array}{l}\text { Simultaneous renal and } \\
\text { testicular mass }\end{array}$ & $\begin{array}{l}\text { Biopsy Left } \\
\text { renal mass } \\
\text { and left radical } \\
\text { orchiectomy } \\
\text { through } \\
\text { laparotomy } \\
\text { incision } \\
\text { - Chemo } \\
\text { - Abdominal RT }\end{array}$ & Spermatic cord & Not available \\
\hline 3 & $\begin{array}{l}\text { De Camereago } \\
\text { et al. }{ }^{3}\end{array}$ & 60 & Rt & $\begin{array}{l}\text { Lt } \\
\text { Epidydimis }\end{array}$ & $\begin{array}{l}7 \text { m Post Radical } \\
\text { Nephrectomy } \\
\text { (Hydrocele was present } \\
\text { at index admission ) }\end{array}$ & $\begin{array}{l}-\quad \text { HIO } \\
-\quad \text { Chemo } \\
\text { - } \quad \text { lung RT }\end{array}$ & Epidydimis & Lost Follow up \\
\hline 4 & Sauter et al. ${ }^{4}$ & NA & $\mathrm{Lt}$ & $\mathrm{Lt}$ & $\begin{array}{l}3 \text { m Post Radical } \\
\text { Nephrectomy }\end{array}$ & $\begin{array}{ll}\bullet & \mathrm{HIO} \\
\bullet & \text { Chemo }\end{array}$ & $\begin{array}{l}\text { Testis, paratesticular } \\
\text { soft tissue, spermatic } \\
\text { cord, spermatic vein }\end{array}$ & Not available \\
\hline 5 & Quattara et al..$^{5}$ & ${ }^{5} \mathrm{NA}$ & $\mathrm{Rt}$ & $\mathrm{Rt}$ & $\begin{array}{l}\text { Massive bilateral } \\
\text { testicular mass with small } \\
\text { renal mass }\end{array}$ & $\begin{array}{l}\text { Radical } \\
\text { nephrectomy } \\
\text { with bilateral } \\
\text { partial } \\
\text { orchectomy } \\
\text { - Chemo } \\
\text { - RT tumor bec } \\
\text { and bilatera } \\
\text { testis. }\end{array}$ & $\begin{array}{l}\text { Testis, spermatic vein } \\
\text { d } \\
\text { al }\end{array}$ & Not available \\
\hline 6 & Trob et al. ${ }^{6}$ & 36 & $\mathrm{Rt}$ & $\mathrm{Rt}$ & $\begin{array}{l}\text { I I m Post Radical } \\
\text { Nephrectomy } \\
\text { (Hydrocele was present } \\
\text { at index presentation) }\end{array}$ & $\begin{array}{l}-\quad \mathrm{HIO} \\
-\quad \text { Chemo }\end{array}$ & testis & NED $8.5 \mathrm{yr}$ \\
\hline 7 & Aydin et al. ${ }^{7}$ & 36 & $\mathrm{Lt}$ & Rt paratesticular & $\begin{array}{l}6 \text { m Post Radical } \\
\text { Nephrectomy } \\
\text { (Hydrocele was present } \\
\text { at index presentation) }\end{array}$ & $\begin{array}{ll}- & \text { HIO } \\
- & \text { Chemo } \\
- & \text { Abdominal RT }\end{array}$ & $\begin{array}{l}\text { Tunica vaginalis, tunica } \\
\text { albuginea }\end{array}$ & $\begin{array}{l}\text { NED alive at } \\
22 \mathrm{~m}\end{array}$ \\
\hline
\end{tabular}


Table Continued..

\begin{tabular}{|c|c|c|c|c|c|c|c|c|}
\hline S.No. & Author's & $\begin{array}{l}\text { Age } \\
\text { (M) }\end{array}$ & $\begin{array}{l}\text { Wilms' } \\
\text { tumor Side }\end{array}$ & $\begin{array}{l}\text { Testicular } \\
\text { metastasis Side }\end{array}$ & $\begin{array}{l}\text { Presentation of } \\
\text { testicular mass }\end{array}$ & $\begin{array}{l}\text { Treatment of testicular } \\
\text { metastasis }\end{array}$ & $\begin{array}{l}\text { Histopathology } \\
\text { of testicular } \\
\text { SPECIMEN }\end{array}$ & Outcome \\
\hline 8 & Daher et al. ${ }^{8}$ & & $\mathrm{Rt}$ & $B / L$ & 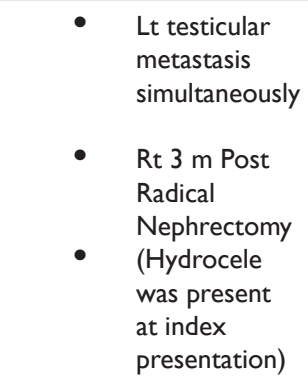 & $\begin{array}{ll}\text { - } & \text { HIO With } \\
& \text { Biopsy Renal } \\
\text { mass } \\
\text { - } \quad \text { Chemo } \\
\text { - } \\
\text { Abdominal RT }\end{array}$ & $\begin{array}{l}\text { Tunica vaginalis, tunica } \\
\text { albuginea }\end{array}$ & $\begin{array}{l}\text { NED alive at } \\
22 \mathrm{~m}\end{array}$ \\
\hline 9 & Yang et al. ${ }^{9}$ & $3 m$ & $\mathrm{Lt}$ & $\mathrm{Lt}$ & $\begin{array}{l}2 \text { month after Radical } \\
\text { nephrectomy }\end{array}$ & $\begin{array}{l}\text { - } \quad \text { Adjuvant chemo } \\
\text { followed by } \\
\text { HIO } 2 \text { month } \\
\text { later }\end{array}$ & NA & Not available \\
\hline 10 & Palmer et al..$^{10}$ & 84 & $\mathrm{Lt}$ & $\mathrm{B} / \mathrm{L}$ testicular mass & $\begin{array}{l}\text { Renal mass (stage Iv) } \\
\text { with lung metastasis and } \\
\text { simultaneous testicular } \\
\text { mass }\end{array}$ & $\begin{array}{l}\text { - Neo adjuvant chemo } \\
\text { - Radical nephrectomy } \\
\text { with bilateral partial } \\
\text { orchiectomy } \\
\text { - adjuvant Chemo, } \\
\text { - Abdominal and Lung RT }\end{array}$ & NA & NED 8 yrs \\
\hline II & $\begin{array}{l}\text { Kajbafzaden } \\
\text { et al." }\end{array}$ & 60 & $\mathrm{Rt}$ & $\mathrm{Rt}$ & $\begin{array}{l}\text { Simultaneously renal and } \\
\text { testicular mass }\end{array}$ & $\begin{array}{l}\text { - HIO with } \\
\text { Radical } \\
\text { nephrectomy, } \\
\text { - } \quad \text { adjuvant chemo, } \\
\text { - abdominal RT }\end{array}$ & & $\begin{array}{l}\text { Recurrence in } \\
\text { abdomen }\end{array}$ \\
\hline 12 & Ansari et al. ${ }^{12}$ & 33 & $B / L$ & $\mathrm{Rt}$ & $\begin{array}{ll}\text { - } & \text { Rt } \\
\text { - } & 3 \mathrm{~m} \text { later } \\
\text { incidentally } \\
\text { diagnosed B/L } \\
\text { WT. } \\
\text { During } \\
\text { Treatment } \\
\text { of WT mass } \\
\text { detected in } \\
\text { right scrotum }\end{array}$ & $\begin{array}{l}\text { Neoadjuvant } \\
\text { Chemo -radio } \\
\text { therapy } \\
\text { Biopsy renal } \\
\text { mass } \\
\text { biopsy } \\
\text { testicular mass }\end{array}$ & Spermatic cord & $\begin{array}{l}\text { Died in } \\
2 \text { month } \\
\text { progressive } \\
\text { liver and } \\
\text { pulmonary } \\
\text { metastasis }\end{array}$ \\
\hline 13 & Singh et al. & 42 & $\mathrm{Lt}$ & $\mathrm{Lt}$ & $\begin{array}{l}\text { Simultaneous renal and } \\
\text { testicular mass }\end{array}$ & $\begin{array}{l}\text { Biopsy renal } \\
\text { mass and radical } \\
\text { orchiectomy } \\
\text { through } \\
\text { laparotomy } \\
\text { incision } \\
\text { Neoadjuvant } \\
\text { Chemo } \\
\text { Abdominal RT }\end{array}$ & Testis, spermatic vein & Lost Follow up \\
\hline
\end{tabular}

The frequency of metastasis to the testis is very low, only $2 \%$ of the testis tumors are metastatic. ${ }^{20}$ A firm intratesticular mass should be considered cancer until proven otherwise, so we must exclude the primary testicular tumor before labeling as testicular metastasis. ${ }^{21}$ In any testicular mass, the serum marker of primary testicular malignancy (AFP, HCG, LDH-1) should be performed. AFP levels are elevated in $70 \%$ of low-stage non seminomatous germ cell tumor (NSGCT) and $80 \%$ of advanced NSGCT. ${ }^{22,23}$ The choriocarcinomas and seminomas do not produce AFP. hCG levels are elevated in $40 \%$ of low-stage NSGCT and $60 \%$ of advanced NSGCT. hCG is also secreted by seminoma (15\%) choriocarcinoma and Embryonal carcinoma. ${ }^{23}$ Hence both these tumor marker have great utility in diagnosing primary testicular malignancy. But, AFP or hCG levels in the normal range didn't rule out Germ Cell Tumor. ${ }^{10,23}$ The renal and simultaneous testicular mass with normal serum marker of testicular malignancy, we should have a differential of Germ cell tumor or WT with testicular metastasis. The dictum also holds true for the children, where testicular mass is identified long after primary surgery of WT. ${ }^{8,10}$ In these case radical inguinal orchiectomy (removal of tumorbearing testis and spermatic cord to the level of internal inguinal ring) should be done with the primary management of WT. There is no role of fine needle aspiration cytology of testicular mass. ${ }^{23,24}$ During radical orchiectomy through high inguinal approach, early clamping of cord should be done before handling the testicular mass to decrease the chance of tumor embolization. ${ }^{8,10}$ Testis-sparing surgery /partial orchiectomy can also be done for bilateral testicular tumor $(<2 \mathrm{~cm}$ in size) or tumor in a solitary testis with sufficient testicular androgen production. ${ }^{8,23,10}$ Testis sparing surgery has no role in suspected testicular neoplasm with a normal contra lateral testis. ${ }^{10}$ 
The literature analysis suggested retrograde venous or retrograde lymphatic extension as the most common mode of testicular metastasis. ${ }^{1-12,24}$ Other suggested mode of testicular metastasis are hematogenous and transcoelomic (associated patent processus vaginalis). Transcoelomic mode is the most probable explanation for testicular metastasis to contra-lateral side of primary renal tumor. ${ }^{1-6}$ Six cases showed presence of hydrocele at index presentation of WT who developed testicular metastasis, average 6 month after radical nephrectomy. These patients develop clinical testicular metastasis with local recurrence after radical nephrectomy, which suggests possible mechanism as tumor spillage and spread through patent process vaginalis. ${ }^{2,5,6}$ The author suggests if there is patent processes vaginalis (PPV), herniotomy should be done at the time of Radical nephrectomy to reduce surgical and tumor related morbidity. ${ }^{8}$ Another possible explanation for the cases where clinical testicular metastasis developed long after/during primary treatment of WT can be, presence of subclinical metastatsis in the testis (missed on clinical examination). ${ }^{12}$ A PPV has been estimated to be present in $80-95 \%$ of all male newborns, declining to $60 \%$ at one year of age, $40 \%$ at two years, and $15-37 \%$ thereafter. ${ }^{25}$ It allows the passage of intraperitoneal contents (fluid, blood, tumor metastasis) between the abdomen and scrotum. Only $20 \%$ of PPV presents clinically as inguinal hernia or hydrocele during their lifetime. ${ }^{25}$ In author's opinion in view of up to $95 \%$ subclinical patent PPV, routine ultrasonography of scrotum (screening for testicular metastasis) with abdominal ultrasound can be a cost effective screening measure which might reduce the child tumor related morbidity and mortality. If we found any sonographic finding of solid or mixed cystic lesion mass than surgical exploration of concern testis should be done through high inguinal approach. ${ }^{26}$ The author invites prospective studies in the subject, for analysis of cost effectiveness and manpower and time utilization.

In adult the most frequent primary tumors metastatic to the spermatic cord and epididymis are carcinomas from the stomach (transcoelomic spreads, $42.8 \%$ ) and the prostate (retrograde venous, lymphatic spread $28.5 \%$ ). Only $9.5 \%$ of adult testicular mass are the first sign of an occult neoplasm, similar to outtara et al (1/12 patient pediatric patient). ${ }^{13-15}$ In adult $23.8 \%$ of testicular metastases are subclinical and when discovered the wrong diagnosis made concerning the origin of the primary tumor. In $47.6 \%$ of adults cases, the metastases and the primary tumor are found simultaneously similar to pediatric cases ( $4 / 11$ cases, $36.6 \%)$. The adult testicular metastatic cancer (primary any abdominal organ) patient has poor survival (average 9.1 month subsequent to the diagnosis of the metastasis. ${ }^{13-15}$ The average survival in pediatric patient varied from 8 years $(2$ cases $)$ to fulminant disease progression and death within 2 months ( 2 cases). So, author suggested the primary histology of tumor and not the status of testicular metastasis is the prognostic factor in these patients. To conclude radical orchiectomy/ partial orchiectomy should be done simultaneous to management of WT (nephrectomy in resectable / incisional biopsy and lymph node sampling in unresctable WT) if testicular and renal mass were present simultaneously. The route of testicular metastasis (retrograde, hematogenous, transcoelomic) will not change the stage and prognosis of patient having WT.

\section{Acknowledgements}

None.

\section{Conflict of interest}

The authors declare no conflict of interest.

\section{Funding}

None.

\section{References}

1. Dew H. Sarcomatous tumors of the testicle. Surg Gynecol Obstet. 1928;46:447-458.

2. Yadav K, Pathak IC. Wilms' tumor with left cord metastasis. Br J Urol. 1977;49(6):536.

3. de Camargo B, Pinus J, Lederman H, et al. Intrascrotal metastasis from Wilms' tumor. Med Pediatr Oncol. 1988;16(6):381-383.

4. Sauter ER, Schorin MA, Farr GH Jr, et al. WTwith metastasis to the left testis. Am Surg. 1990;56(4):260-262

5. Tröbs RB, Friedrich T, Lotz I, et al. Wtmetastasis to the testis:long-term survival. Pediatr Surg Int. 2002;18(5-6):541-542.

6. Aydin GB, Ciftçi AO, Yalçin B, et al. Paratesticular metastasis from Wilms tumor associated with a hydrocele. Pediatr Blood Cancer. 2006;47(1):97-99.

7. Daher P, Raffoul L, Riachy E. Bilateral testicular metastasis from Wilms' tumor. Eur J Pediatr Surg. 2010;20:415-416.

8. Yang YJ, Xiang B, Liu JX, et al. Ultrasound in diagnosis of intrascrotal metastasis of Wilms' tumor:first case report of a Chinese boy and review of the literature. J Med Ultrason. 2015;42(4):575-578.

9. Palmer BW, Xiong Y, Gherezghiher A, et al. Wilms' tumor metastatic to bilateral testes at presentation:case and review of the literature. Urology. 2012;79(4):899-901.

10. Ouattara K, Daffe S, Timbely. A Cancer of the kidney revealed by massive tumoral invasiveness of the testis. Apropos of a case in a child. J Urol (Paris). 1992 98:60-61.

11. Kajbafzadeh AM, Javan-Farazmand N, Baghayee A, et al. Paratesticular metastasis from Wilms tumor:the possible routs of metastasis and literature review. J Pediatr Hematol Oncol. 2011;33:e347-e349.

12. Ansari S, Miri-Aliabad G, Rakhshani N. Bilateral Wilms' Tumor Metastasis to Right Spermatic. CordInt J Hematol Oncol Stem Cell Res. 2013;7(4):45-48.

13. Marković B, Oprić M, Prica V, et al. Metastasis in the spermatic cord as the first sign of a malignant kidney tumor. Srp Arh Celok Lek. 1983;111(1):87-91.

14. Algaba F, Santaularia JM, Villavicencio H. Metastatic tumor of the epididymis and spermatic cord. Eur Urol. 1983;9(1):56-59.

15. Kaneko Y, Okita H, Haruta M, et al. A high incidence of WT1 abnormality in bilateral Wilms tumors in Japan, and the penetrance rates in children with WT1 germline mutation. Br J Cancer. 2015;112(6):1121-1133.

16. Deng C, Dai R, Li X, Liu F. Genetic variation frequencies in Wilms' tumor:A meta-analysis and systematic review. Cancer Sci. 2016;107(5):690-699.

17. Orlowski JP, Levin HS, Dyment PG. Intrascorotal Wilms' tumor developing in a heterotopic renal anlage of probable mesnephric origin. J pediatr surg. 1980;15:679-682.

18. Godzinski J. The current status of treatment of Wilms' tumor as per the SIOP trials. J Indian Assoc Pediatr Surg. 2015;20(1):16-20.

19. Tournade MF, Com-Nougué C, Voûte PA, et al. Results of the Sixth International Society of Pediatric Oncology Wilms' Tumor Trial and Study:A risk-adapted therapeutic approach in Wilms' tumor. J Clin Oncol. 1993;11(6):1014-1023.

20. Akbal C, Erdem E, Hamada H, et al. Prostatic cancer with metastasis to the testis. Turk J Cancer. 2001;31(1):35-38. 
21. Sarıcı H, Telli O, Eroğlu M. Bilateral testicular germ cell tumors. Turk J Urol. 2013;39(4):249-252.

22. Wei Y, Wu S, Lin T, He D, Li X, et al. (2014) Testicular yolk sac tumors in children:a review of 61 patients over 19 years. World J Surg Oncol $12: 400$.

23. Jenny E Elzinga-Tinke, Gert R Dohle, Leendert HJ Looijenga. Etiology and early pathogenesis of malignant testicular germ cell tumors:towards possibilities for preinvasive diagnosis. Asian J Androl. 2015;17(3):381393.
24. Hanash KA, Carney JA, Kelalis PP. Metastatic tumors to testicle:Routs of metastasis. J Urol. 1969;102(4):465-468.

25. Watson DS, Sharp KW, Vasquez JM, et al. Incidence of inguinal hernia diagnosed during laparoscopy. South Med J. 1994;87(1):23-25.

26. Shtricker A, Silver D, Sorin E, et al. The value of testicular ultrasound in the prediction of the type and size of testicular tumors. Int Braz J Urol. 2015;41(4):655-660. 